\title{
GPR-Derived Sedimentary Architecture and Stratigraphy of Outburst Flood Sedimentation Within a Bedrock Valley System, Hraundalur, Iceland
}

\author{
Jonathan L. Carrivick $^{1 *}$, Jamie K. Pringle ${ }^{2}$, Andrew J. Russell ${ }^{3}$ and Nigel J. Cassidy ${ }^{2}$ \\ ${ }^{1}$ School of Geography, University of Leeds, Leeds, West Yorkshire, LS2 9JT, U.K. \\ ${ }^{2}$ Earth Sciences and Geography, Keele University, Keele, Staffordshire, ST5 5BG, U.K. \\ ${ }^{3}$ School of Geography, Politics and Sociology, Daysh Building, University of Newcastle, Newcastle Upon Tyne, \\ Northumbria. NE1 7RU, U.K.
}

*Correspondence Tel. +44 (0)113 343 3324; Email j.1.carrivick@leeds.ac.uk

\begin{abstract}
Jökulhlaups and lahars are both types of outburst flood that commonly comprise a glacial meltwater and volcaniclastic sediment mix, and have discharges that are typically several orders of magnitude greater than perennial flows. Both types thus constitute a serious threat to life, property and infrastructure but are too powerful and too short-lived for direct measurements of flow characteristics to be made. Consequently a variety of indirect methods have been used to reconstruct flow properties, processes and mechanisms. Unfortunately, limited observations of sedimentary architecture and stratigraphic relationships are hampering our ability to discriminate fluvial magnitude-frequency regimes and fluvial styles of deposition, particularly those produced by rapidly-varied flows. This paper therefore uses Ground Penetrating Radar (GPR) to obtain quantitative data on subsurface sedimentary character of high-magnitude outburst flood sediments, including architecture and stratigraphy, from a bedrock-valley system in north-central Iceland. Basement pillow lava and subaerial lava flows are characterised by chaotic and hummocky GPR reflectors with a lack of coherent structure. They also feature an upper rough surface as evidenced by concentration of hyperbolae point sources. Unconsolidated sedimentary units are interpreted due to occur where laterally-persistent horizontal and sub horizontal reflectors occur. Deposition produced spatially diverse sediments due to rapidlyvaried flow conditions. Observations include prograding and backfilling architecture, intercalated slope material and fluvial sediments, and multiphase sedimentary deposition. We suggest that these outburst flood sediments were initially deposited by traction load of coarsegrained material on prograding bedforms, and subsequently by drop-out from suspension of finer-grained material. The latter phase produced laterally extensive tabular sedimentary architectures that in-filled pre-existing topography and masked the complexity of bedrock forms beneath. Existing qualitative concepts of high-magnitude fluvial deposition within a topographically confined bedrock channel are therefore now refined with quantitative data on sediment architecture and thus on flow regimes.
\end{abstract}

\section{Introduction and Rationale}

Outburst floods are a sudden release of water and sediment with discharges that are several orders of magnitude greater than perennial flows (Costa and Schuster, 1988; Clague and Evans, 2000). Jökulhlaups and lahars are two types of outburst flood that commonly comprise glacial meltwater and volcaniclastic sediment. A variety of sources and trigger mechanisms exist for the generation of jökulhlaups (e.g., Maizels and Russell, 1992; Tweed and Russell, 1999) and lahars, but both are frequently associated with a sudden release of impounded water. Impounded water can be rapidly released due to the failure of an ice, moraine or volcanic sediment dam (e.g., Costa and Schuster, 1988), or from a landslide, for example (e.g., Scott et al., 2001; Waythomas and Wallace, 2002). Volcanic and geothermal activity can directly generate high-magnitude floods by instantaneous melting of ice and snow. Where glaciers and volcanoes coincide, jökulhlaups and lahars become indistinct from each other, since both comprise glacially-derived meltwater and volcaniclastic sediment. On the basis of sediment concentration, the term jökulhlaup typically becomes reserved for fluid flows, and the term lahar to mass slurry flows or granulised flows. However, jökulhlaups have been noted to become progressively more fluidal as sediment supply is exhausted (e.g., Maizels, 1993; Russell and Marren, 


\section{Journal of Environmental and Engineering Geophysics}

1999; Carrivick et al., 2004b). Some outburst events involve sediment volumes much greater than the transporting water volume (Haeberli, 1983; Lliboutry et al., 1977). Initially fluid lahars can become 'bulked' by rapid sediment entrainment (Manville, 2004; Cronin et al., 1997; Scott et al., 2001; Lavigne and Thouret, 2003).

Jökulhlaups and lahars occur worldwide and constitute a serious threat to life, property and infrastructure (Haeberli, 1983; Costa and Schuster, 1988; Haeberli et al., 1989; Björnsson, 1992, 2002; Evans and Clague, 1993; Richardson and Reynolds, 2000; Chester et al., 2001). With climate change causing extreme weather and increased glacial melt (IPCC, 2001), it is not unreasonable to suggest that high-magnitude outburst floods will increase in frequency, and perhaps also in magnitude. Jökulhlaups and lahar hazards are primarily due to direct impacts, caused by a surge frontal wave, from debris within the main flow body, and from the mass and consistency of a flow itself (e.g., Iverson, 1997; Carrivick, 2006). A number of secondary impacts also pose hazards, including widespread deposition of sediment and post-lahar flooding caused by blocked tributary streams (e.g., Simkin et al., 2001; Witham, 2005). Jökulhlaups and lahars erode both unconsolidated sediments (e.g., Russell and Marren, 1999; Gomez et al., 2002) and bedrock (e.g., Baker, 1988; Tómasson, 2002; Carrivick et al., 2004a). Subsequent transport and deposition of a vast amount of sediment (e.g., $10^{8}$ tons; Björnsson, 2002) can produce a suite of diverse and sometimes distinctive landforms (Haeberli et al., 1989; Desloges and Church, 1992; Cenderelli and Wohl, 2003).

Landforms and sediments produced by outburst floods have received considerable attention due to the difficulty of making direct measurements of flow characteristics. High-magnitude outburst floods are simply too sudden, too powerful, too short-lived and often occur within relatively inaccessible locations, for direct measurements of flow characteristics to be possible. Consequently, jökulhlaup landforms and sediments have been described, interpreted and classified. Thus conceptual models of jökulhlaup flow dynamics, flow rheology and the control of jökulhlaup magnitude and frequency on proglacial geomorphology and sedimentology, have been developed (Maizels, 1993, 1997; Maizels and Russell, 1992; Rushmer et al., 2002; Marren, 2005; Rushmer, 2006, in press; Russell et al., 2006).

To date, conceptual models of outburst flood landforms and sediments have been limited to surface observations and natural exposures. The exception is a study by Rushmer (in press) of jökulhlaup hydrograph shape controls on sedimentation. Consequently, the large-scale (hundreds of meters) sedimentary architec- ture of outburst flood deposits is largely unknown, and specific modes of deposition are largely undocumented. Cassidy et al., (2003) illustrated that GPR methods can distinguish sedimentary bedding in outburst flood sediments and infer sequential modes, phases and rates of outburst flood deposition.

Outburst flood deposits within rapidly-varied outburst floods, such as those within bedrock channels have received great attention for palaeoflood reconstructions. This is because where they occur within tributary valley mouths, embayments and alcoves they are ascribed to be palaeostage indicators (e.g., Baker et al., 1983). However, outburst flood deposit emplacement mechanisms are poorly understood due to an absence of observations of flow characteristics and of sedimentary architecture. Hypotheses for the emplacement of outburst flood deposits within bedrock channel embayments and alcoves are i) suspension drop-out (Baker and Kochel, 1988; O'Connor, 1993) and ii) traction processes in eddy currents (Kochel and Baker, 1988; Smith, 1993; Russell, 1996). Smith (1993) suggests that outburst flood sediments within bedrock tributary valleys mouths, embayments and alcoves can form either by 'dynamic flooding' due to flood surges, or by 'passive flooding' due to slowly rising ponded water.

\section{Aim}

This paper will therefore 1) document the sedimentary architecture of outburst flood deposits within a bedrock valley system, and 2) using these data, infer the depositional regime of these deposits, in space and time.

\section{Study Site}

The Kverkfjöll Volcanic System (KVS, Iceland, comprises the Kverkfjöll stratovolcano and the proglacial area of Kverkfjallarani, which is characterised by a series of parallel bedrock ridges that form valley walls (Fig. 1). This paper presents data from the northern, or distal, end of Hraundalur, the largest valley in Kverkfjallarani (Fig. 1). This site is chosen firstly because it contains widespread field evidence of jökulhlaups (Carrivick et al., 2004a, b), and secondly because a preliminary investigation of potential sites has been made by Cassidy et al., (2004). Thirdly, previous research has suggested the flow character of jökulhlaups from Kverkfjöll. These are i) Highly varied flow conditions in space and time, as indicated by a juxtaposition of erosional and depositional styles (Carrivick et al., 2004a, 2004b; Carrivick and Twigg, 2004), and ii) Flows capable of geomorphic work comparable to that of the Missoula, Bonneville and Altai megafloods, 


\section{Carrivick et al.: GPR-Derived Sedimentary Architecture}

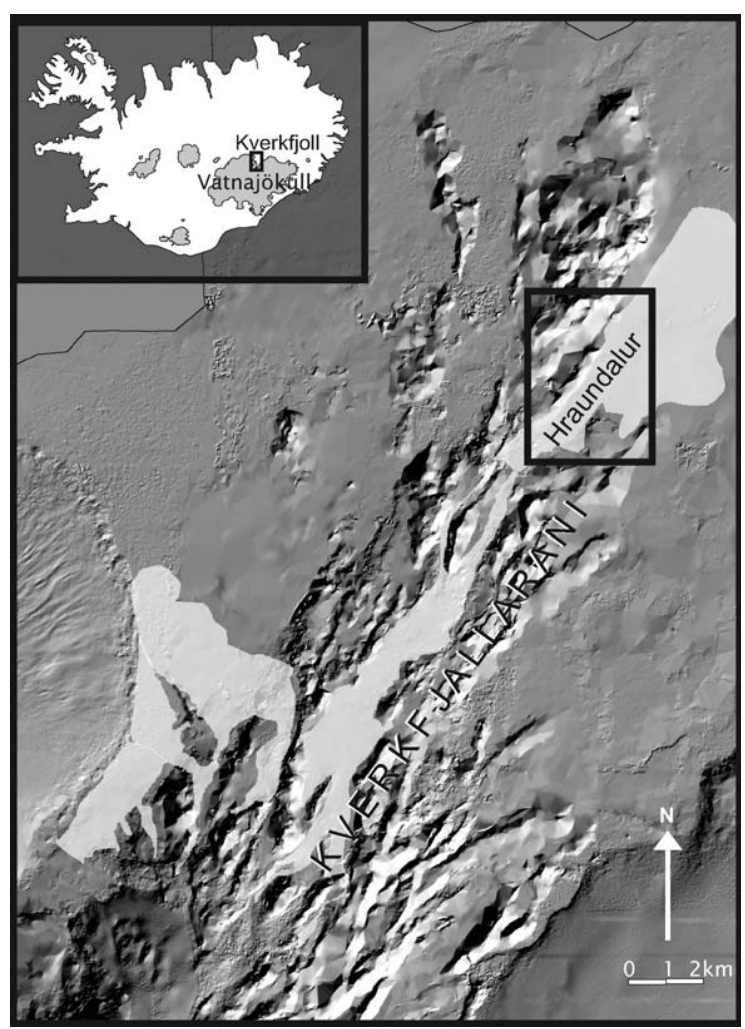

Figure 1. Kverkfjallarani location map showing the GPR study site. Figure 2 location indicated by box.

despite peak discharge being at least an order of magnitude lower (Carrivick, 2006). Fourthly, a highresolution (10 $\mathrm{m}$ horizontal grid with sub-metre vertical accuracy) Digital Elevation Model (DEM) of Kverkfjallarani has been constructed (Carrivick and Twigg, 2004; Fig. 1), so that jökulhlaups could be modelled for spatial and temporal variations in hydraulic parameters (Carrivick, 2006, in press). Therefore results from this study can be correlated with sedimentary surface and pit observations, and compared with 2D hydrodynamic modelling results. It should be noted that there is currently very little surface water drainage in Hraundalur and that snow melt simply percolates into the highly permeable sediments.

\section{Method}

Subsurface data were gathered from three sites marginal to main palaeoflow channel (Carrivick et al., 2004a, 2004b; Carrivick and Twigg, 2004; Carrivick 2006). Some survey profiles were deliberately extended wherever possible into the main channel in order to examine transitional deposition. For convenience, sites are named S1, S2 and S3 (Fig. 2). Main land surface types present in Kverkfjallarani are jökulhlaup outwash

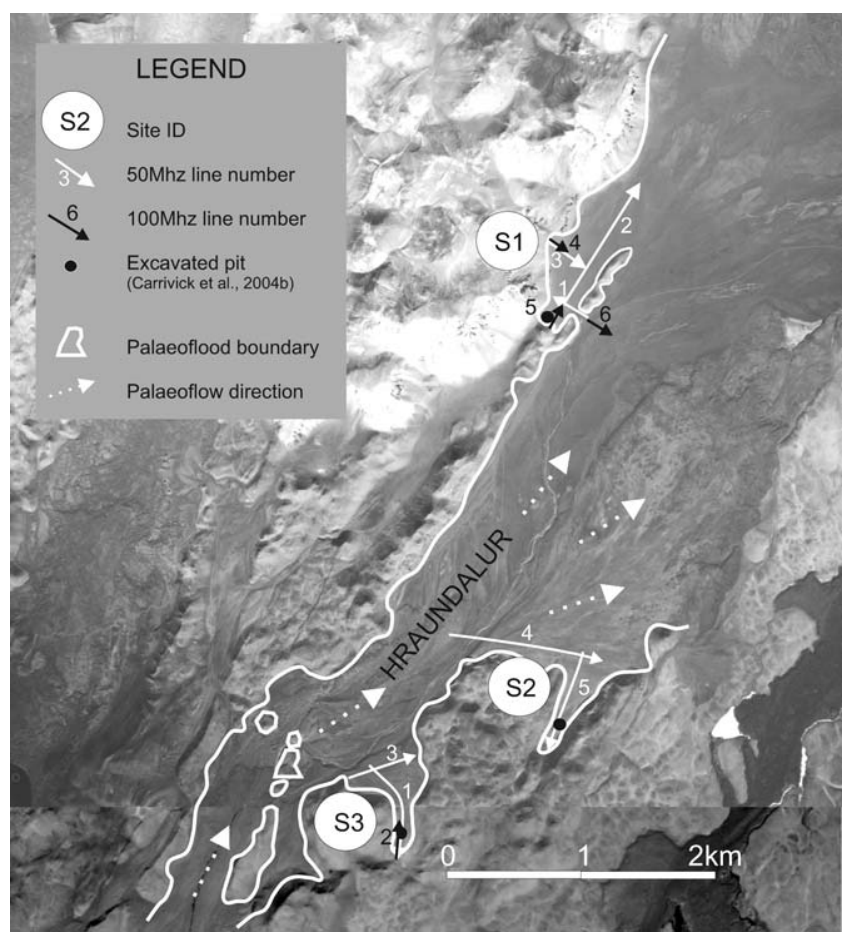

Figure 2. Plan of GPR profiles, sedimentary observations and interpreted palaeoflood boundary. Some sedimentary observations reported by Carrivick et al., (2004b). Palaeoflood boundary is from field-evidence (Carrivick et al., 2004a), and from hydrodynamic modelling (Carrivick, 2006, in press).

and boulder deposits (Fig. 3A), sub-aqueous pillow lavas, subaerial lava flows, and rheomorphic (secondary) deposits (Fig. 3B) derived from flow of semi-molten air-fall such as bombs, spatter, scoria and ash.

Large-scale (hundreds of meters) subsurface sedimentary architecture was gained with an extensive Ground Penetrating Radar (GPR) survey. Multiple 2D profiles $(\sim 1 \mathrm{~km}+)$ were measured using Sensors and Software PulseEKKO $100^{\mathrm{TM}}$ equipment. Dominant frequency $50 \mathrm{MHz}$ antennae were preferentially used to acquire $\sim 7 \mathrm{~km}$ of profiles (Fig. 3C). Additionally, $100 \mathrm{MHz}$ dominant frequency antennae were used in more marginal areas (Fig. 2) to improve resolution. Common Mid Point (CMP) velocity profiles were collected at representative site areas and used to convert profiles from time (nanoseconds) to depth (meters). Typically CMP values were $0.04 \mathrm{~m} \mathrm{~ns}^{-1}, \quad 0.05 \mathrm{~m} \mathrm{~ns}^{-1}, \quad 0.1 \mathrm{~m} \mathrm{~ns}^{-1}$ and 0.012 $\mathrm{m} \mathrm{ns}^{-1}$, thereby allowing a 4-layer model to be differentiated, with differing velocities interpreted to represent the different lithologies present. Sedimentary deposits are $0.05-0.1 \mathrm{~m} \mathrm{~ns}^{-1}$ whereas igneous layers are faster $\left(0.09-0.12 \mathrm{~m} \mathrm{~ns}^{-1}\right)$. GPR surveys are summarised in Table 1. 


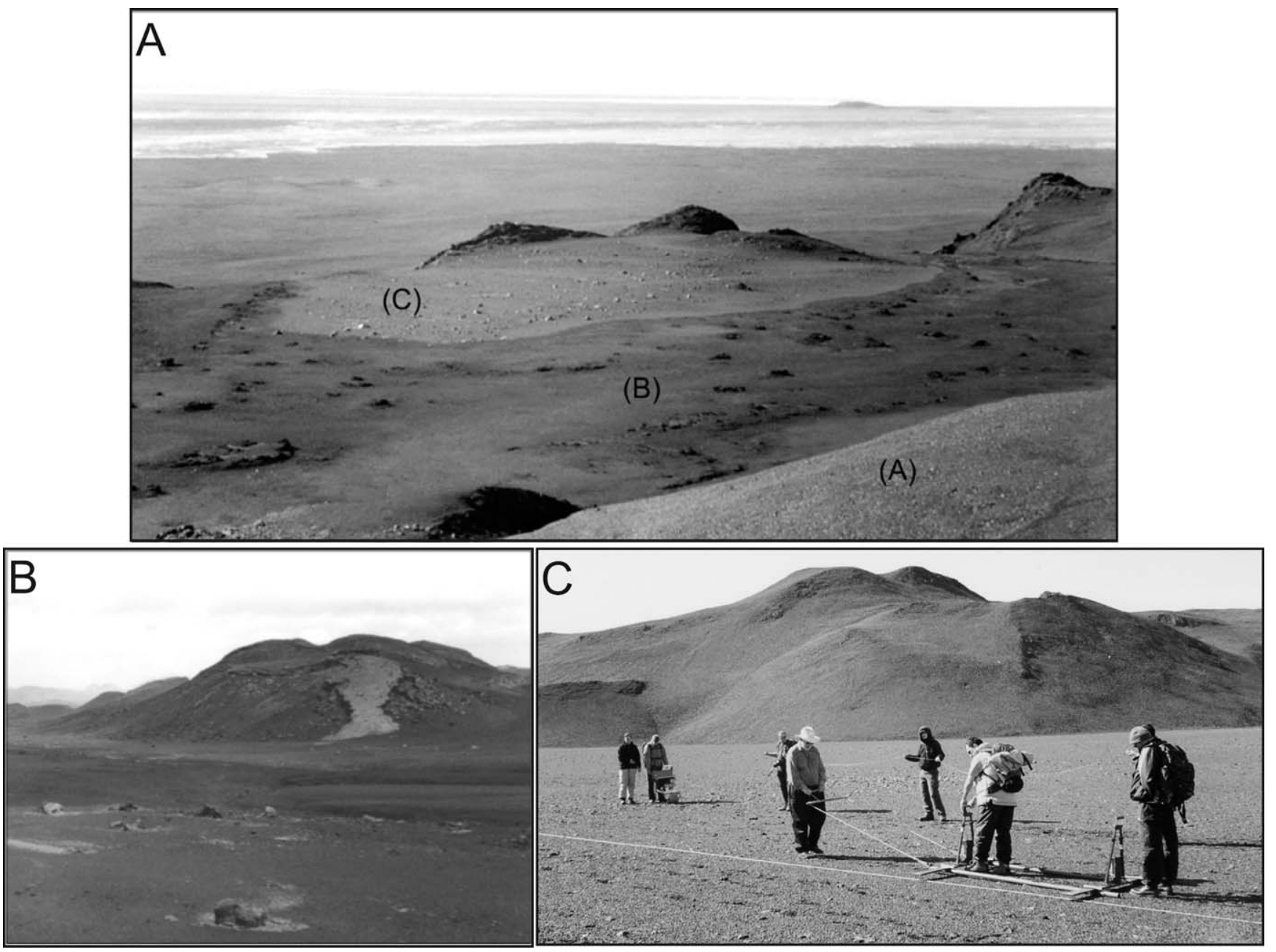

Figure 3. Photographs to illustrate [A] Surface types in Kverkfjallarani; pillow lava scree (A), subaerial lava flow (B) and jökulhlaup outwash and boulder deposits (C). View is from a ridge $200 \mathrm{~m}$ above surface (B), which has a field of view $\sim 500 \mathrm{~m}$ across. [B] A rheomorphic flow mantling ridges with jökulhlaup outwash and boulder deposits in foreground. Note considerable break-up and erosion of rheomorphic material and contrast with valley floor sediments. Ridge is $\sim 500 \mathrm{~m}$ from camera, and field of view is also $\sim 500 \mathrm{~m}$ across. [C] Acquisition of a 2-D, $50 \mathrm{MHz}$ GPR profile at Little Hrandular (LH) study site.

GPR profile positions were marked with survey poles for a subsequent topographic survey to correct GPR profiles for any surface slope variations. Profiles were surveyed by conventional total station (theodolite) methods over a three-day period, using 374 control points at $\sim 10 \mathrm{~m}$ intervals along $2 \mathrm{D}$ profiles or at significant breaks of slope. Re-siting of the survey station along profiles was sometimes necessary due to unusually long profile lengths (three profiles exceeded $1 \mathrm{~km}$ in length).

Survey co-ordinates of each $1 \mathrm{D}$ GPR trace (at $0.5 \mathrm{~m}$ or $0.25 \mathrm{~m}$ spacing, for the $50 \mathrm{MHz}$ and $100 \mathrm{MHz}$ data respectively) were interpolated from the survey information, and incorporated into GPR header files. Each 2D GPR profile was then processed within
REFLEX software to optimise image quality (Table 2). Profiles were converted to depth using the topographic survey data and the site-specific CMP average velocity. Different velocity traces were resolved within the CMP profile, implying several distinctly separate substrate types.

\section{Results}

For brevity, and particularly to avoid exhaustive description, results concentrate on key aspects of GPR profiles, and distinguishing different GPR facies. Point source refractions or hyperbolae have been separated out from laterally continuous horizontal and subhorizontal surfaces and steeper-angled structures, based 
Carrivick et al.: GPR-Derived Sedimentary Architecture

Table 1. Summary of GPR data collected by this research.

\begin{tabular}{|c|c|c|c|c|c|c|c|}
\hline Site & Profile & $\begin{array}{c}\text { Frequency } \\
\text { (MHz) }\end{array}$ & Time/window (ns) & $\begin{array}{c}\text { Number of 1D } \\
\text { stacks }\end{array}$ & Step size (m) & Total distance (m) & $\begin{array}{c}\text { Number of } \\
\text { traces }\end{array}$ \\
\hline \multirow[t]{7}{*}{1} & L1 & 50 & 1,000 & 16 & 0.5 & 444 & 889 \\
\hline & $\mathrm{L} 2$ & 50 & 1,000 & 16 & 0.5 & 1,200 & 2,401 \\
\hline & CMP-1 & 50 & 1,000 & 16 & 0.25 & 13 & 53 \\
\hline & L3 & 50 & 1,000 & 16 & 0.5 & 517 & 1,035 \\
\hline & $\mathrm{L} 4$ & 100 & 500 & 32 & 0.25 & 200 & 801 \\
\hline & L5 & 100 & 500 & 32 & 0.25 & 60 & 241 \\
\hline & L6 & 50 & 1,000 & 16 & 0.5 & 200 & 401 \\
\hline \multirow[t]{4}{*}{2} & $\mathrm{~L} 4$ & 50 & 1,000 & 16 & 0.5 & $1,299.5$ & 2,361 \\
\hline & L5 & 50 & 1,000 & 16 & 0.5 & 713 & 1,427 \\
\hline & $\mathrm{L} 5 \mathrm{~b}$ & 50 & 1,000 & 16 & 0.5 & 307 & 615 \\
\hline & CMP-2 & 50 & 1,000 & 16 & 0.25 & 30 & 57 \\
\hline \multirow[t]{6}{*}{3} & $\mathrm{~L} 1$ & 50 & 1,000 & 16 & 0.5 & 1,024 & 2,049 \\
\hline & L1b & 50 & 1,000 & 16 & 0.5 & 30 & 61 \\
\hline & CMP-3a & 50 & 1,000 & 16 & 0.25 & 30 & 61 \\
\hline & L2 & 100 & 500 & 32 & 0.25 & 120 & 481 \\
\hline & L3 & 50 & 1,000 & 16 & 0.5 & 690 & 1,381 \\
\hline & CMP-3b & 50 & 1,000 & 16 & 0.25 & 57 & 128 \\
\hline
\end{tabular}

entirely on the position and relationship of identifiable GPR reflectors, and thus on signal coherence and continuity. Note that within some units structures suggest smaller strata. GPR facies are thus discriminated and interpreted for lithological/sedimentary character. Distinctive water table reflections were not observed and therefore the signal penetration was consistently excellent; typical penetration depths were $\sim 30-40 \mathrm{~m}$. Since the parabolic approximation of reflection/ diffraction hyperbolae is only valid for short off-sets, all instances of point source reflections are assumed to be diffraction hyperbolae. Additionally, it is acknowledged that hyperbolae could be more evident at $50 \mathrm{MHz}$ than at $100 \mathrm{Mhz}$ due to a larger antennae, lower frequency and a larger footprint. Also note that due to multiple GPR profiles at each of the three sites, the convention for labelling is as follows; where S2L3 denotes Site 2, GPR profile (line) 3.

Site 1.

$\mathrm{S} 1 \mathrm{~L} 1$ is a $50 \mathrm{Mhz}$ dominant frequency survey that cuts across Site 1, which is a valley marginal to the main Hraundalur (Fig. 2). The same transect is continued at $100 \mathrm{Mhz}$ dominant frequency by S1L6 (Fig. 2). Reflectors on S1L1 below $\sim 10 \mathrm{~m}$ depth are dominated by a series of point reflector diffraction hyperbolae (Fig. 4A). This is also the case for S1L6, although on S1L1, well within the main Hraundalur valley, the lowermost reflector rises from 20 to $10 \mathrm{~m}$ depth, over $200 \mathrm{~m}$ horizontal distance (Fig. 4A). It can be noted that many more point reflector diffraction hyperbolae are observed on the main Hraundalur valley on S1L1,

Table 2. GPR 2-D profile processing steps of this research.

\section{GPR Processing steps}

1. Input raw GPR data file into REFLEX processing software.

2. DC-Shift filter already applied, DEWOW filter applied to normalise varying trace strengths.

3. Gain filter applied to amplify deeper reflection events.

4. Elevation mute applied to remove air signal.

5. Elevation statistics applied from topographic survey.

6. CMP average velocity derived and used to convert from time (nanoseconds) to depth (meters).

7. Diffraction hyperbolae matching for improved velocity-depth analysis.

8. Attribute; instantaneous frequency, phase and amplitude analysis all used to assist in profile interpretation and reflector 'tracing'. 

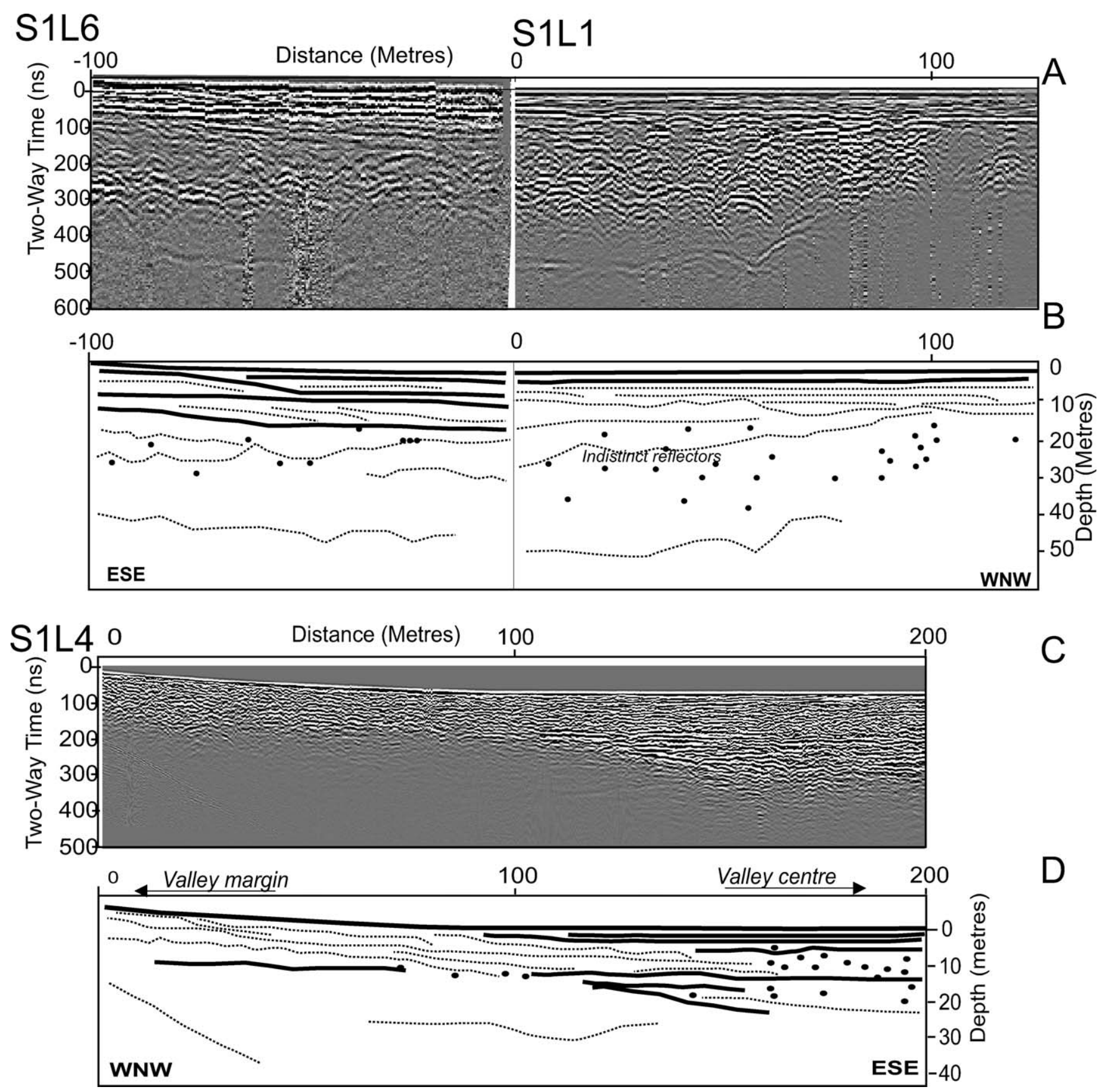

Figure 4. Site 1: S1L1 (50 MHz) and S1L6 (100 MHz) GPR profile (A) and GPR interpretation (B) are on the same transect (see Fig. 2). S1L4 (50 Mhz) GPR profile (C) and GPR interpretation (D) are on a separate transect (see Fig. 2). Significant diffraction events are represented by small points located at the apex of diffraction hyperbolae. The topographically corrected time-zero ground surface is illustrated by a continuous solid line at the top of each sub-section.

than in the marginal valley on S1L6 (Fig. 4B). Reflectors above $10 \mathrm{~m}$ in S1L1 are mainly horizontal and ill-defined, whilst in S1L6 they are better defined and sub-horizontal, with an apparent dip into the marginal valley (Fig. 4B).

S1L4 is also a $100 \mathrm{MHz}$ dominant frequency survey that focuses on a lateral slope of Site 1 (Fig. 2).
Signal penetration is just $\sim 15 \mathrm{~m}$ at the extreme edge of the marginal valley, but steadily increases to $\sim 25 \mathrm{~m}$ towards the marginal valley centre (Fig. 4C). Lowermost reflectors are generally incoherent throughout (Fig. 4C), but has more point source diffraction hyperbolae towards the marginal valley centre (Fig. 4C). Reflectors also feature many more point source reflec- 


\section{Carrivick et al.: GPR-Derived Sedimentary Architecture}

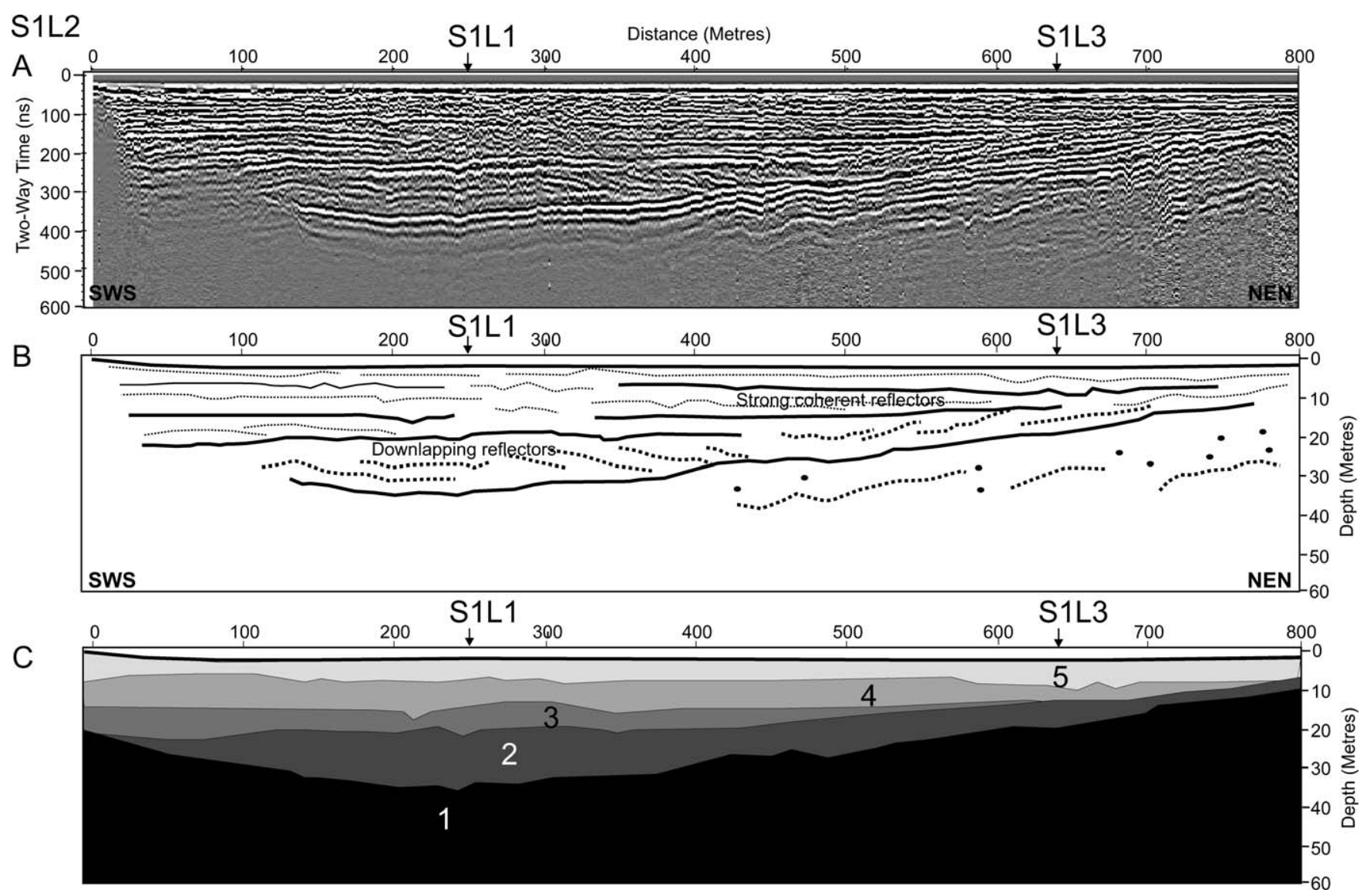

Figure 5. S1L2. GPR profile (A), and GPR interpretation (B). Significant diffraction events are represented by small points located at the apex of diffraction hyperbolae. The topographically corrected time-zero ground surface is illustrated by a continuous solid line at the top of each sub-section. The GPR interpretation permits inference of sequential deposition of sedimentary units 1-5 (C).

tors at depth, but are dominated by strong, coherent and continuous horizontal reflectors towards the valley centre (Fig. 4D). Towards the edge of the marginal valley facies boundaries are weak but continuous and generally dip in accordance with the surface slope (Fig. 4D).

The long axis of the Site 1 valley is imaged by the $50 \mathrm{MHz}$ dominant frequency GPR profile S1L2 (Fig. 2). S1L2 shows a coherent reflective lowermost boundary in the SWS reach of LH. This layer is at $\sim 35 \mathrm{~m}$ depth below the surface and rises to become less distinct at just $\sim 15 \mathrm{~m}$ depth at the NEN reach (Fig. 5A). Above this boundary are a series of downlap reflectors that have an apparent gradient of $10 \mathrm{~m}$ in $100 \mathrm{~m}$ (Fig. 5B). This dip is in an apparent direction towards the NEN in the centre section of the profile, and in a SWS direction at the NEN end of the profile (Fig. 5B). The uppermost $\sim 15 \mathrm{~m}$ of S1L2 comprises largely horizontal thin beds with some structure (Fig. 5B).
Site 2.

$\mathrm{S} 2 \mathrm{~L} 4$ is a $\sim 1,200 \mathrm{~m} 50 \mathrm{MHz}$ dominant frequency survey that extends from the main Hraundalur valley, over a small active channel, and thence across the mouth of a tributary valley (Fig. 2). Lowermost reflectors along S2L4 (Fig. 6A) vary considerably, but with the absence of a water table penetration is excellent to $\sim 50 \mathrm{~m}$. Below $5 \mathrm{~m}$ depth from the surface, no distinctive structures are discriminated (Fig. 6B), because reflectors are generally weak and incoherent at depth, but within $10 \mathrm{~m}$ of the surface are strong and coherent (Fig. 6B). Reflectors have a general dip in accordance with the surface slope (Fig. 6B).

S2L5 is a $\sim 1,000 \mathrm{~m} 50 \mathrm{MHz}$ dominant frequency survey extending from the mouth to the head of a tributary valley (Fig. 2). It should be noted that whilst traversing into the valley, the surface elevation decreases (Fig. 7A). Lower reflectors along S2L5 are generally incoherent and defined by a series of interfering diffraction hyperbolae, which are most prevalent from 


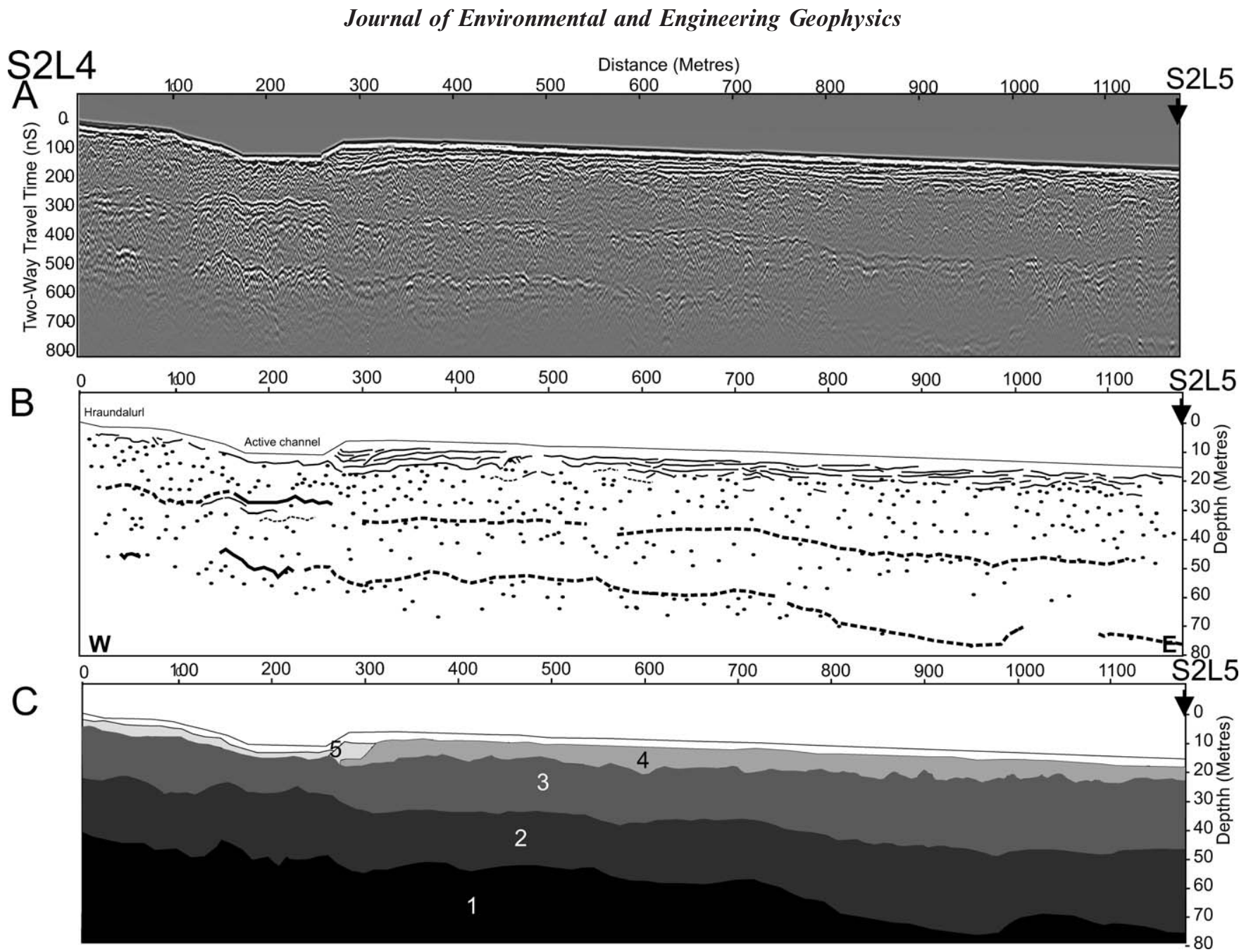

Figure 6. S2L4. GPR profile (A), and GPR interpretation (B). Significant diffraction events are represented by small points located at the apex of diffraction hyperbolae. The topographically corrected time-zero ground surface is illustrated by a continuous solid line at the top of each sub-section. The GPR interpretation permits inference of sequential deposition of sedimentary units 1-5 (C).

0-500 $\mathrm{m}$, and gradually descend from $10-35 \mathrm{~m}$ over this distance (Fig. 7B). From 500-1,000 m more distinct reflectors gradually rise from $35-10 \mathrm{~m}$ depth, with a peak at $900 \mathrm{~m}$ distance (Fig. 7B).Facies boundaries (reflectors) along S2L5 tend to follow lowermost reflector slopes, although reflectors closer to the surface become progressively more planar (Fig. 7B).

\section{Site 3.}

S3L1 was surveyed with a $50 \mathrm{MHz}$ dominant frequency from north to south, from the mouth of a tributary valley to its head (Fig. 2). The surface of $\mathrm{S} 3 \mathrm{~L} 1$ is a very gentle dome with $6 \mathrm{~m}$ of relief (Fig. 8A). However, lowermost reflectors form a series of anticlinal and synclinal structures, and other reflectors are overall rather more horizontal (Fig. 8B). In detail, lowermost reflectors are extremely hummocky, though reasonably strong and coherent, except where point source diffrac- tion hyperbolae break up the reflection. Facies boundaries become increasingly laterally extensive, strong and coherent with proximity to the surface (Fig. 8B). Facies thicknesses vary considerably, and where contacts occur with lower hummocky reflectors, give rise to a series of on-lapping structures with an apparent gradient of $10 \mathrm{~m}$ over $600 \mathrm{~m}$ (Fig. 8B).

S3L3 was surveyed with a $50 \mathrm{MHz}$ dominant frequency from west to east, across the mouth of a tributary valley to the main Hraundalur valley (Fig. 2). Whilst the surface slope of S3L3 is nearhorizontal, there is an undulating lowermost reflector (Fig. 9A). The lowermost reflector is strong, but discontinuous. There is an extremely incoherent reflector with a dome-like structure at $50 \mathrm{~m}$ along the survey profile (Fig. 9A). The lowermost reflector pattern of S3L3 can imply a basal topography that has an apparent dip from east to west and from $\sim 20 \mathrm{~m}$ to 
Carrivick et al.: GPR-Derived Sedimentary Architecture

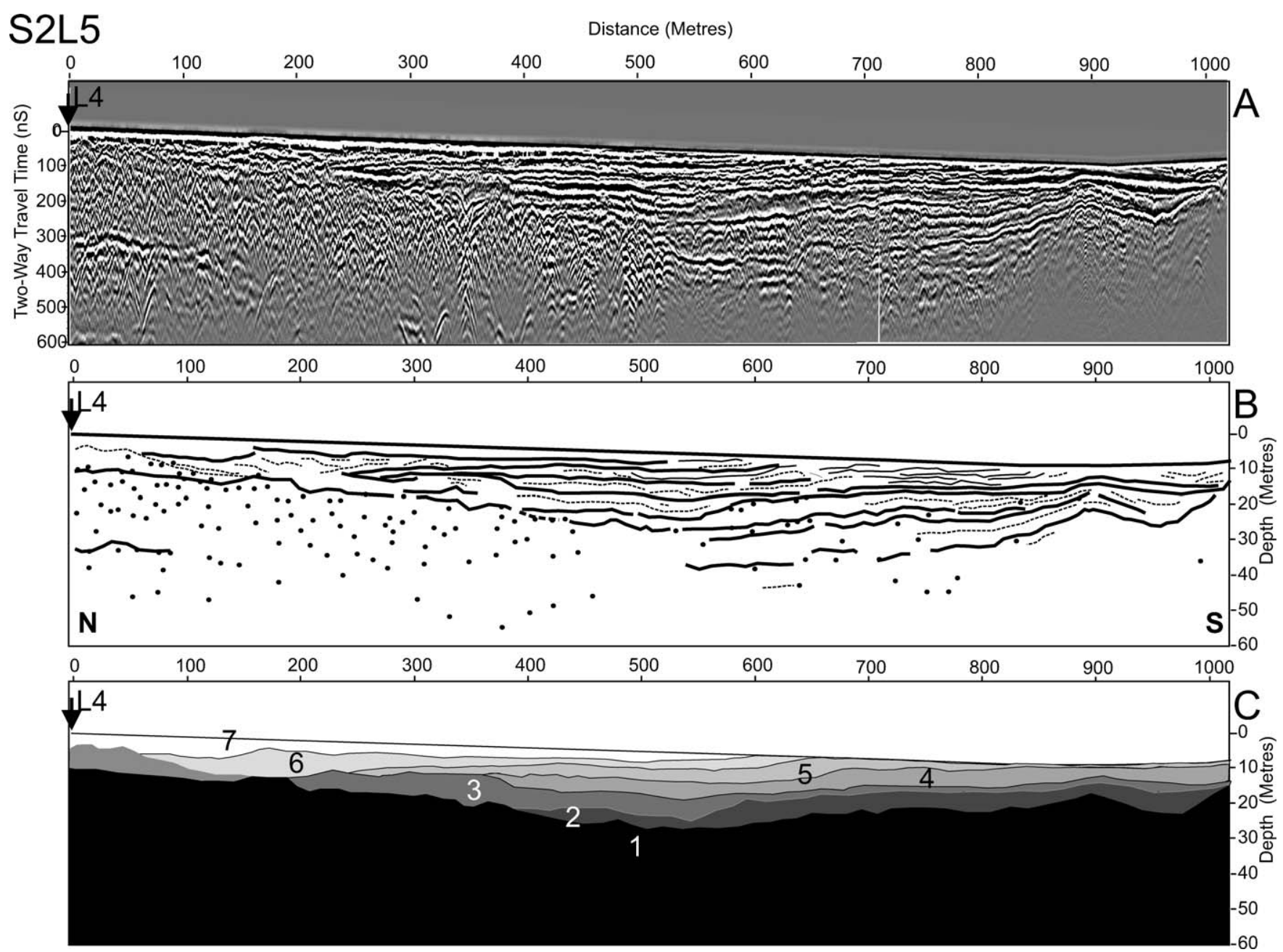

Figure 7. S2L5. GPR profile (A), and GPR interpretation (B). Significant diffraction events are represented by small points located at the apex of diffraction hyperbolae. The topographically corrected time-zero ground surface is illustrated by a continuous solid line at the top of each sub-section. The GPR interpretation permits inference of sequential deposition of sedimentary units 1-7 (C).

$\sim 30 \mathrm{~m}$ below the surface over $\sim 600 \mathrm{~m}$ horizontal distance (Fig. 9B). The exception to this is the domelike structure at $50 \mathrm{~m}$ along the survey profile. Middepth reflectors on S3L3 are discriminated into two major GPR facies. The lowermost is characterised by a single laterally extensive dipping unit with frequent point source diffraction hyperbolae (Fig. 9B). The uppermost reflectors are horizontal, and characterised by much thinner reflector spacing, an absence of point diffraction hyperbolae, and with stronger and more coherent reflectors (Fig. 9B).

\section{Interpretation of GPR and Sedimentology}

\section{Site 1.}

GPR interpretations at S1L1 and S1L6 reveal two distinct facies. The first is a series of incoherent reflections that are dominated by point diffraction hyperbolae (Fig. 4B). This unit is interpreted to be bedrock, most likely highly fragmented and occasionally brecciated basement volcanic rock, which in Kverkfjallarani, is typically pillow lava (Fig. 3A). The second major facies observed on the S1L1-S1L6 transect comprises a series of weak but coherent and generally continuous horizontal and sub-horizontal reflectors (Fig. 4B). This unit is interpreted to be a series of unconsolidated sedimentary units. The fact that some of these units form foresets that dip from the main Hraundalur valley on S1L6, and that they are all horizontal on S1L1 (Fig. 4B), suggests progradation of these sediments from the main valley.

S1L4 is interpreted to have a similar bedrock to that of S1L1 and S1L6, i.e., brecciated pillow lava, as indicated by the weak, incoherent reflector and frequent 


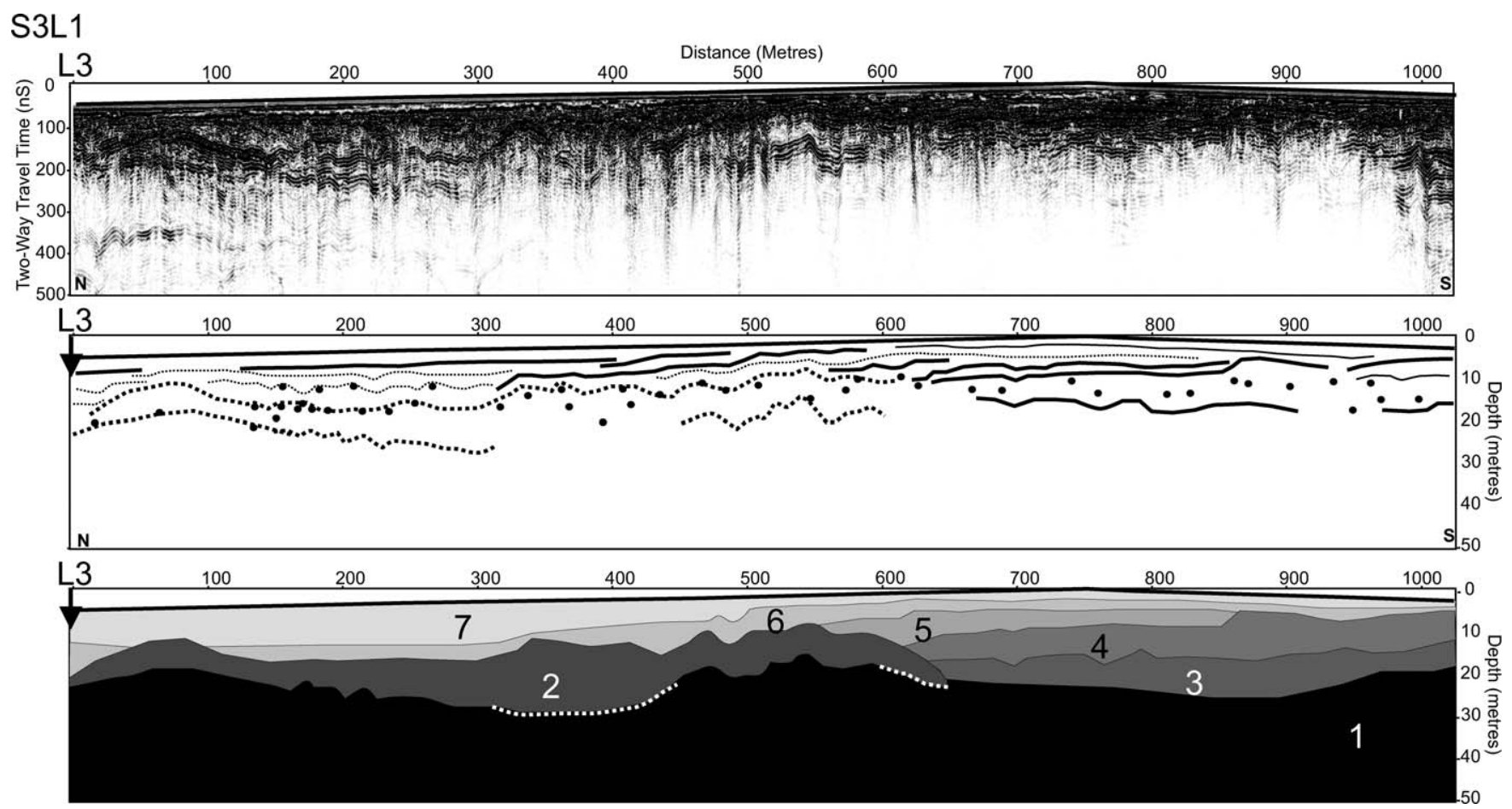

Figure 8. S3L1. GPR profile (A), and GPR interpretation (B). Significant diffraction events are represented by small points located at the apex of diffraction hyperbolae. The topographically corrected time-zero ground surface is illustrated by a continuous solid line at the top of each sub-section. The GPR interpretation permits inference of sequential deposition of sedimentary units 1-6 (C). The base of unit 2 is interpolated where denoted by a white dashed line.

point diffraction hyperbolae (Fig. 4D). Reflectors are interpreted to be unconsolidated sedimentary units of two types. One type is situated towards the marginal valley centre and comprises material with more distinct units, which are horizontal. These units are underlain by a unit broken by point source reflectors, which are probably boulders. The other type is situated towards the marginal valley side and comprises material dipping parallel to the surface slope and of indistinct character. It is possible that the former material is coarser and the latter material is finer, given the differences in reflector strength, although any dielectric variation could account for this change.

Strong and coherent lowermost reflections in the SWS reach of S1L2 (Fig. 5A) could either indicate the presence of a relatively smooth subaerial lava flow surface, perhaps eroded, or very fine-grained sediment in-filling the topographic low, for example. The second unit is interpreted to be unconsolidated fluvial sediments which are exotic i.e., not sourced from local slopes, since the dipping reflectors (Fig. 5C) indicate prograding sediment deposition. Units $3-5$ in S1L2 (Fig. 5C) are interpreted to be unconsolidated sediments that are characterised by; generally fining upwards planar beds, as indicated by progressively closer and less distinct reflectors. It should be noted that beds could also appear to become thinner towards the surface as GPR wavelength increases with depth and thus beds are more precisely resolved at lower depths. It is worth noting that sediments along S1L2 are probably more homogenous than those in the main Hraundalur valley, as indicated by comparison with S1L6, where sediments feature very incoherent beds, numerous boulders and considerably thinner deposits (Fig. 4B).

\section{Site 2.}

Along S2L4, units 1-3 are all interpreted to be pillow lava. This interpretation is based upon unit thickness, a lack of coherent facies structure, and a upper blocky rough surfaces as evidenced by concentrations of hyperbole point sources (Fig. 6C). The latter property is thought to be incompatible with subaerial lava flows. Units 4 and 5 are interpreted as sedimentary because of the presence of coherent structures of a horizontal and sub horizontal nature (Fig. 6C). However, it is clear that units 4 and 5 are separated by an erosional contact which defines unit 5 as inset into the terrace edge (Fig. 6C).

The lowermost unit; Unit 1, in S2L5 (Fig. 7C) is interpreted as bedrock pillow lava. Unit 2 (Fig. 7C) could also be bedrock (Fig. 7C). Unit two could therefore be a subaerial lava flow, or a rheomorphic 


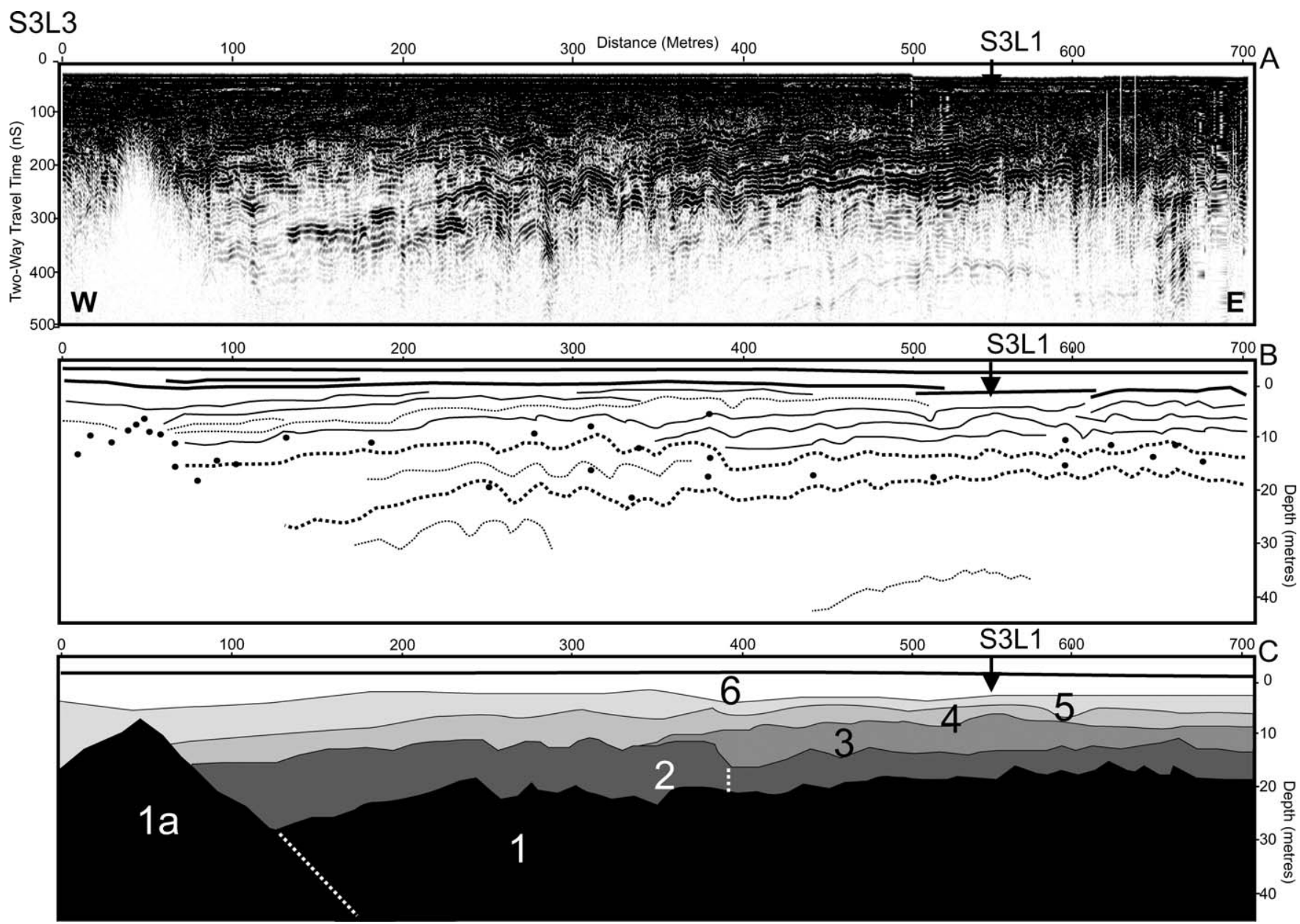

Figure 9. S3L3. GPR profile (A), and GPR interpretation (B). Significant diffraction events are represented by small points located at the apex of diffraction hyperbolae. The topographically corrected time-zero ground surface is illustrated by a continuous solid line at the top of each sub-section. The GPR interpretation permits inference of sequential deposition of sedimentary units 1-6 (C).

deposit (Fig. 3B). Other units in Fig. 7C are interpreted as unconsolidated sediments and are labelled in the most likely order of deposition. This sedimentary deposition can be viewed as a series of infilling events, which sequentially drape over and then subdue underlying topography. It is also interesting to note that units 4 and 5 are confined to the innermost part of the tributary valley, whilst units 6 and 7 are confined to the outermost part of the tributary valley (Fig. 7C).

\section{Site 3.}

S3L1 is interpreted to comprise 7 distinct units. The lowermost unit; Unit 1 (Fig. 8C), is interpreted to be basement pillow lava on the basis of a lack of coherent structure, and rough surface, as marked by frequent point diffraction hyperbolae (Fig. 8B). Unit 2 (Fig. 8C) is most likely to be a subaerial lava flow, due to its relatively uniform thickness, hummocky but coherent upper boundary, and a lack of structure (Fig. 8B). Units 3-7 are interpreted as unconsolidated sediments (Fig. 8C). This interpretation is due to the properties of much thinner units, horizontal, subhorizontal and some dipping reflectors, and some laterally extensive reflectors (Fig. 8B).

S3L3 is rather more complicated than S3L1. The domal reflector at $50 \mathrm{~m}$ along S3L3 (Fig. 9A) is situated along a line continuing from a pillow lava ridge immediately to the south (Fig. 2). This domal reflector could therefore represent a rheomorphic mantle of lava and airfall material over a bedrock outcrop, such as that depicted in Fig. 3B. On the basis of its individual topography, this bedrock outcrop could be a separate feature to Unit 1 bedrock beneath the rest of S3L3 (Fig. 9C). Unit 2 is interpreted to be a subaerial lava flow on the basis of its laterally continuous but weak and rough; point source reflector hyperbole) surface 


\section{Journal of Environmental and Engineering Geophysics}

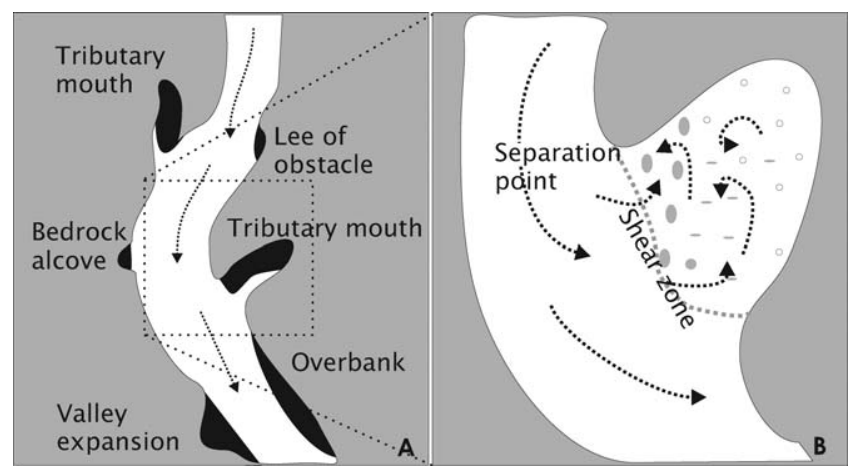

Figure 10. Schematic representation of the most common locations for sedimentation within confined valley and bedrock settings (A), redrawn from Baker and Kochel (1988), and typical flow conditions associated with eddy deposit formation (B), adapted from O'Connor (1993).

(Fig. 10C). This buried subaerial lava is therefore interpreted to be similar to that depicted in Fig. 3A. Due to the sudden change in thickness of this unit, and the diffraction of reflectors about this point (Fig. 9B), it is possible that this unit is actually two separate subaerial lava flows (Fig. 9C). Units 3 and 4 feature much stronger and more coherent reflectors, with thinner depths, and an absence of point diffraction hyperbolae (Fig. 9B). These sediments are therefore interpreted to be unconsolidated sedimentary units (Fig. 9C). Unit 3 is interpreted to infill accommodation space afforded by the abutment of the thicker lava flow and the thinner lava flow. Units 4, 5 and 6 (Fig. 9C) have some parallel reflectors, some of which are subhorizontal and all of which are laterally extensive (Fig. 9B). Units 4, 5 and 6 are therefore interpreted to represent widespread sedimentary in-filling of Site 3, with depositional units becoming sequentially thinner, and also thinner towards the east (Fig. 9C).

\section{Discussion}

This discussion will proceed through four parts. Firstly, we will consider what processes caused the interpreted sedimentary formations at each site, i.e., the style of deposition, before secondly presenting a conceptual model of sedimentation. Thirdly, the nature of sedimentary materials within each of the facies will be discussed. Fourthly and finally, a comparison of the inferred styles of deposition will be made with previous models.

\section{$\underline{\text { Processes of Formation }}$}

GPR facies at sites 1, 2 and 3 are of two very distinct types, and these have been presented in the preceding sections to imply the stratigraphic position of i) basement bedrock comprising pillow lava, ii) subaerial lava flows, and iii) overlying unconsolidated sedimentary units. It is these sedimentary units that will be discussed hereon. Sedimentary accumulation processes will be inferred from the large-scale (hundreds of meters) arrangement of units, i.e., from the sedimentary architecture, the nature of stratigraphic contacts, unit thickness, lateral extent and bedding.

Overlying sedimentary units at sites 1,2 and 3 are generally horizontally extensive and comprise continuous bedding. They are therefore indicative of simultaneous and coherent deposition over a widespread area. However, close inspection reveals subtle differences between sites, between separate GPR profiles, and also within individual profiles.

Dipping units are interpreted as prograding features, and series of dipping sedimentary beds are interpreted as foresets. Laterally extensive horizontal stacks of beds suggest widespread low-energy deposition, or deposition at highest stage. A well-defined or 'sharp' contact between adjacent units infers an erosional event, sufficiently large enough to erode underlying sediments and to subsequently bury them.

Site 1 is interpreted to be a topographic basin, on the basis of lowermost reflector topography. The basin is defined in part by chaotic and hummocky reflectors, which are interpreted to represent highly brecciated pillow lava, and a coherent but irregular 'rough' surface that is interpreted to be a subaerial lava flow. The lava flow is only present in the main Hraundalur valley, as interpreted in S1L6 (Fig. 4B), and at the mouth of the Site 1 valley, as interpreted at the northern end of S1L2 (Fig. 5B). In-filling this basin is a succession of unconsolidated sediment, most likely derived from the main valley of Hraundalur, due to the prograding structures that dip from the east in S1L6 (Fig. 4B), and from the north in S1L2 (Fig. 5B). These structures are thus interpreted as foresets. The fact that upper sedimentary units at Site 1 become progressively more shallow, and with less distinct reflectors between units, is interpreted to be a function of declining grain size variations between beds and probably therefore a fining upwards trend.

Processes of formation at Site 2 are interpreted from two distinctly different GPR profiles. S2L4 features two buried subaerial lava flows, and thin $(>10 \mathrm{~m})$ overlying sediments, whilst S2L5 does not obviously contain a subaerial lava flow; although there is a possibility of one at the northern end of the profile, at $35 \mathrm{~m}$ depth, and up to $\sim 30 \mathrm{~m}$ thickness of overlying unconsolidated sediment. It is therefore interpreted that subaerial lava flows have inundated Hraundalur (Carrivick et al., 2004a) and expanded across the mouth of Hraundalur, as revealed by the GPR in Fig. 6A. 


\section{Carrivick et al.: GPR-Derived Sedimentary Architecture}

However, on the basis of GPR profile S2L5 (Fig. 7A), these lava flows did not inundate the tributary valley that is Site 2. This spatial arrangement of lava flows is in contrast to overlying sediments at site 2 , which are of a far greater depth and complexity well within the tributary valley; as observed in S2L5 (Fig. 7A), than across the tributary valley mouth, as observed in S2L4 (Fig. 6A). Furthermore, overlying sediments across the tributary valley mouth are largely within shallow $(\sim 3 \mathrm{~m}$ thick) horizontal and laterally continuous beds (Fig. 6C). In contrast, overlying sediment well within the tributary valley are sub-horizontal, form a synclinal architecture and comprise more and thicker beds (Fig. 7C). Deposition across the tributary valley mouth is thus interpreted to be spatially and temporally uniform, whilst within the valley deposition has varied in space, and comprised distinct episodes. The major exception to this overview is a feature at $\sim 300 \mathrm{~m}$ along S2L4 (Fig. 6A). This feature is a strong erosional contact between units 4 and 5 (Fig. 6B). This erosional contact defines Unit 5 as inset into the terrace (surface topography) edge and implies an erosional event, sufficiently large enough to erode Unit 4 sediments and to subsequently bury them. This erosional event could also explain the absence of units 4 and 5 from the northern end of S2L5 (Fig. 7C).

Site 3 features the most irregular lowermost reflector topography of all three sites. The three domes in S3L1 (Fig. 8C), and the single major dome-like structure in S3L3 (Fig. 9C), are interpreted to be subaerial extensions of the topographic ridges in the area (Fig. 2), and thus to be composed of pillow lava. A subaerial lava flow, most likely one that routed along the main Hraundalur valley (Carrivick et al., 2004a), is interpreted throughout in S3L1 (Fig. 8C), but only in the northern part of S3L3 (Fig. 9C). After emplacement of the subaerial lava flow, deposition at Site 3 is interpreted to have proceeded through distinct episodes and to have comprised unconsolidated sediments. This is evidenced by strong and coherent stratigraphic contacts throughout S3L1 (Fig. 8B) and S3L3 (Fig. 9B). The absence of Unit 3 in the eastern part of S3L1 (Fig. 8C), and of units 3-5 in the northern part of S3L3 (Fig. 9C) implies considerable and widespread reworking and erosion in these areas.

GPR diffraction hyperbolae, which mark isolated boulders within the sediment, further distinguish these layered sediments from lava flows, because lava flows are massive and would not therefore produce diffraction hyperbolae. It is therefore suggested that these sediments are products of a high-magnitude glacial outburst flood, or 'jökulhlaup'. Whether these sediments are the product of a single jökulhlaup, or whether they are the result of more than one jökulhlaup, requires some further stratigraphic analysis and consideration of additional data.

\section{Conceptual Model}

Unconsolidated sediments interpreted in the upper profiles at Site 1, Site 2 and Site 3 are collectively interpreted to be slackwater deposits. This is because these sediments are clearly exotic, being of a sedimentology and having a stratigraphy that is incompatible with hypotheses of slope deposits or mass movement. Furthermore, whilst the sedimentary architecture is consistent with fluvial deposition, the structure dimensions (hundreds of meters), and the absence of any modern-day surface runoff in the area, means that these sediments are most likely to be the result of a jökulhlaup that routed along the main valley of Hraundalur. Such a jökulhlaup would have been of sufficient stage to cause flow to enter Site 1 through a low col, which is now submerged, and back up the tributary valleys at Site 2, and Site 3. This phenomena is evidenced by the interpreted prograding bedforms, which could reflect deposition from bedload. It is reasonable to suggest that flow in sites 1, 2 and 3 were not sufficiently powerful to significantly modify pre-existing surface topography, although clearly some reworking of pre-existing sediments has persisted at all the sites. Flow recirculation at all sites is evidenced by lowermost beds that show considerable variation in the orientation of dip. In cases where sub-horizontal strata has an apparent dip against the regional slope deposition from within recirculation eddys is invoked. For note, these dipping strata are not backsets in antidunes because flow energy was very low at these sites (Carrivick, 2005, 2006), and because the typical Froude number value reconstructed for sites 1, 2 and 3 is just $0.1-0.2$ (Carrivick, 2005).

Following peak discharge, deposition of finergrained material from suspension is suggested at all sites by thinner $\sim 1 \mathrm{~m}$ thick planar beds that are uniformly horizontal, irrespective of either bed topography or any underlying dipping beds. The depositional mechanism responsible for planar beds is most likely to have been suspension drop-out, although the presence of some structure could argue against this hypothesis since the beds are clearly not entirely massive. Furthermore, these planar beds refute models of multiple events, repeated fluvial incursions, and altering magnitude and frequency regimes, since they would have been produced by consistently shallow and slow flows. Such flows have been reconstructed across sites 1, 2 and 3 by Carrivick, (2006) with flow depths of $0.5-1.8 \mathrm{~m}$, and velocities of 1.1-1.4 $\mathrm{ms}^{-1}$. These flows would be most unlikely to support sustained currents and hence unlikely to produce bedforms. Added to this is the fact that the very low apparent bed gradients (typically $10 \mathrm{~m}$ over 


\section{Journal of Environmental and Engineering Geophysics}

$1,000 \mathrm{~m}$ ) would be very unfavourable conditions for coarse material moving in traction, and rather suggest suspension drop-out.

Whether these jökulhlaup sediments are the product of a single jökulhlaup, or of several outburst floods, is difficult to determine. However, with regards to the GPR profiles, an argument for multiple jökulhlaups is evidence by several features. Firstly, S1L4 (Fig. 4D) is interpreted to document slope deposits that intercalate outburst flood sediments. There is no possible explanation for slope deposits being delivered at a rate sufficient to intercalate outburst flood sediments. Therefore the presence of intercalated slope sediments with outburst flood sediments strongly suggests that multiple outburst floods have routed down Hraundalur. Furthermore, Carrivick et al., (2004b) made $3 \mathrm{~m}$ deep excavations at the head of Site 1 and also within the embayments of sites 2 and 3 . The location of these excavations is marked in Fig. 2. Carrivick et al., (2004b) report the presence of several distinct orange/yellow fine-grained beds, within each excavated pit, which on the basis of major element analysis could be volcanic air-fall material; 'tephra', or slope-washed palagonite from weathered pillow lava rinds. Therefore, whilst the GPR images down to a typical depth of 35-40 m, even the top $3 \mathrm{~m}$ excavated by Carrivick et al., (2004b) holds evidence of multiple jökulhlaups.

\section{Materials: Sedimentary Character}

The character and calibre (clast size and density distribution) of sedimentary material can in part be inferred from GPR data but must also draw on external field data and some numerical modelling. GPR data; specifically randomly spaced diffraction hyperbolae at varying depths, clearly indicate boulders supported within a finer-grained matrix of sediment, and these interpretations match well with superficial observations of isolated boulders upon outwash surfaces (e.g., Fig. 3A). These boulders are derived from subaerial lava, where the size of boulder is limited to the spacing between vertical cooling joints, typically $1-1.5 \mathrm{~m}$ (Carrivick et al., 2004b). The sediment matrix cannot be categorised for its constituents by GPR interpretations. However, it is clear that this material is dry, and therefore highly porous, because of the absence of a water table and because of excellent GPR signal penetration depths. There is thus almost certainly no silt and clay-sized sediment fractions, rather sand, gravel and cobbles. Since jökulhlaup sediments have superficially been observed in Hraundalur to be heterolithic, very poorly mixed, and with no trends in grain size (Carrivick et al., 2004a), it is most likely that architectural elements, as picked out by GPR, reflect a change in sediment packing, rather than in sediment lithology or calibre (clast size and density). The decreasing thickness of architectural elements towards the surface most likely reflects inundation by successively higher-stage and probably shallower flows, if it assumed that the main channel elevations remained constant (i.e., without aggradation, which would raise the bed and permit inundation of sites 1,2 and 3 with equivalent discharge or even more minor flows), which would have been of progressively less energy, and therefore deposited finergrained sediment. These suggestions are reinforced by Carrivick, (2005, 2006, in press) who made a series of numerical model simulations of jökulhlaups through Hraundalur. They show through hydrodynamic routing that a jökulhlaup would have inundated sites 1,2 and 3, and through hydraulic analysis that at these sites inundation proceeded as both 'passive' ponding, as 'dynamic' recirculation featuring eddy current and minor flow pulses. Typical shear stress across sites 1, 2 and 3 were $19-118 \mathrm{Nm}^{-2}$ (Carrivick, 2006). These sites are thus very low energy zones with respect to jökulhlaups, and it is reasonable to interpret the sedimentary architecture of these deposits, as revealed by the GPR, as widespread deposition of relatively finegrained material with little or no re-activation of preexisting depositional surfaces. Finally, the $3 \mathrm{~m}$ deep excavations of Carrivick et al., (2004b) revealed predominantly horizontally-bedded sediments of sand and fine-medium gravel calibre (exceptionally up to $50 \mathrm{~mm}$ diameter clasts).

\section{Comparison with Previous Models}

Results and interpretations of this paper therefore partly support previous documentation of the situation (Fig. 10A) and character of outburst flood deposits within bedrock valleys (Fig. 10B), but with a few differences. For example, tributary mouth and embayment deposits have been observed to comprise vertical sequences of horizontally bedded sands, silts and clays (Baker, 1973; Baker and Kochel, 1988; Kochel and Baker, 1988; O'Connor, 1993), which is in contrast to the highly permeable gravels documented here. Additionally, this study finds no evidence to support welldeveloped proximal to distal trends in sedimentology, as suggested by Baker, (1973); O'Conner, (1993) and Russell and Knudsen, (1999). These authors tend to suggest that eddy bars grade upstream into slackwater deposits (O'Conner, 1993; Fig. 10B). It should be noted that this study's observations that boulders tend to occur only close to the main channel, rather than deeper within an embayment, and we acknowledge that a GPR cannot resolve grain sizes sufficiently to fully test this hypothesis. 
Carrivick et al.: GPR-Derived Sedimentary Architecture

Table 3. Summary of the major observations and interpretations of this paper

\begin{tabular}{|c|c|c|c|}
\hline & GPR facies & Sedimentary interpretation & $\begin{array}{l}\text { Inferred mode of deposition and } \\
\text { hydraulics }\end{array}$ \\
\hline $\begin{array}{c}\text { Architecture and } \\
\text { stratigraphy }\end{array}$ & $\begin{array}{l}\text { Laterally extensive units that } \\
\text { in-fill topography, with some } \\
\text { intercalation of slope deposits }\end{array}$ & $\begin{array}{l}\text { Exotic sediments (unrelated to } \\
\text { surrounding slopes or to } \\
\text { contemporary processes) }\end{array}$ & - \\
\hline Units & $\begin{array}{l}\text { Horizontal and some } \\
\text { sub-horizontal foresets and } \\
\text { backsets }\end{array}$ & $\begin{array}{l}\text { Massive in-filling, and some } \\
\text { prograding low-relief } \\
\text { bedforms }\end{array}$ & $\begin{array}{l}\text { Suspension drop-out in ponded } \\
\text { areas, and some deposition of } \\
\text { traction load in recirculation } \\
\text { eddys }\end{array}$ \\
\hline Contacts & Smooth, continuous & No erosion or re-working & Entirely depositional \\
\hline Calibre & $\begin{array}{l}\text { Occasional boulders, highly } \\
\text { permeable matrix }\end{array}$ & En-mass deposition & Possibly from supply-limited flows \\
\hline
\end{tabular}

\section{Summary and Conclusions}

The results and interpretations of this paper suggest that the sedimentary architecture and stratigraphy of outburst flood sedimentation within a bedrock valley is relatively simple. However, with inferences of the sedimentology of these deposits, a valuable insight to outburst flood hydrodynamics can be gained. Large scale deposition is partly dependant upon bedrock topography, as flow enters and recirculates within tributary valleys mouths and embayments. This loss of energy causes deposition, formerly by progradation of bedforms of coarse material as stage rises, and latterly by suspension drop out of finer grained sediment following peak stage. This is evidenced by dipping strata that overly bedrock, and by strata that have a predominantly dip from the main valley. Additionally the presence of boulders in these bedforms is indicated by point source reflector diffraction hyperbolae. However, the presence of upper units which are horizontally bedded, coherent and generally without any cut-and-fill structures, strongly suggest that higher-stage flows have a much reduced energy, and that suspension drop-out occurs, thereby filling in topographic hollows. Therefore whilst the presence of sediments is controlled by the inundation of that area; and thus by topography, phases and modes of deposition and thus sedimentary character is rather a function of local and reach-scale hydraulics. The intercalation of fluvial sediments and slope deposits is a strong indicator of multiple events. A summary of the major observation and interpretations of this study are given in Table 3.

In conclusion, new knowledge has been gained from the results and interpretations of this paper. These are that with respect to the sedimentary architecture and stratigraphy of outburst flood deposits within bedrock channels:
- Depositional architecture can be generally characterised by dipping strata which are overlain by horizontal planar beds.

- The former reflect bedforms formed from tractive bedload, and the latter late-stage suspension drop out.

- Deposition within these sites is thus initially controlled by underlying topography (which as a basin promotes flow recirculation), and latterly by flood hydraulics.

With respect to Jökulhlaups that have routed along Hraundalur:

- Stratigraphic intercalation of basin sediments with slope deposits suggests that the entire sequence is most likely to be the product of multiple outburst flood events.

- Smooth and continuous contacts, and an absence of cut and fill structures between units, suggests that these multiple inundation events were entirely lowenergy and non-erosive.

Future work would benefit from applying these GPR methods to other depositional landforms of highmagnitude outburst floods, such as longitudinal bars, marginal terraces, pendant bars and obstacle tails. Higher frequency GPR may provide increased resolution of deposition within rapidly varied flow, such as across zones of flow separation, for example. This data will test current models of landform evolution due to high-magnitude outburst floods, which will be directly relevant for incorporating high-magnitude sedimentation processes into current and future hydrodynamic models.

This study purposefully selected sites of extensive volcaniclastic sediment; which is characteristically dry; without internal moisture or a water table and thus permitting excellent GPR signal penetration. Similar situations would likely exist in most semi-arid land- 


\section{Journal of Environmental and Engineering Geophysics}

scapes, where outburst floods are most effective geomorphological agents.

\section{Acknowledgments}

The Icelandic Research Council and the Nature Conservation Agency gave permission to undertake research in Iceland. GPR equipment was provided by a NERC Geophysical Equipment Facility loan (736). The Earthwatch Institute funded fieldwork during the summer of 2003. The 2003 Earthwatch Team IV volunteers and Andy Gregory, Hugh Deeming and Lucy Rushmer are thanked for invaluable and excellent field assistance. Sira and Elisabet made us very welcome at Sigurdarskali hut during our visit. We thank Adam Booth and Alastair Ruffell for their constructive reviews, which significantly improved this manuscript.

\section{References}

Baker, V.R., 1973, Palaeohydrology and sedimentology of Lake Missoula flooding in eastern Washington: Geological Society of America Special Paper, 144, 1-79.

Baker, V.R., 1988, Flood Erosion, in Flood Geomorphology, Baker, V.R., Kochel, R.C., and Patton, P.C. (eds.), John Wiley and Sons, New York, 81-95.

Baker, V.R., and Kochel, R.C., 1988, Flood sedimentation in bedrock fluvial systems, in Flood Geomorphology, Baker, V.R., Kochel, R.C., and Patton, P.C. (eds.), John Wiley and Sons, New York, 123-137.

Baker, V.R., Kochel, R.C., Patton, P.C., and Pickup, G., 1983, Palaeohydrologic analysis of Holocene flood slackwater sediments: Special Publications of the International Association of Sedimentologists, 6, 229-239.

Björnsson, H., 1992, Jökulhlaups in Iceland: prediction, characteristics and simulation: Annals of Glaciology, 16, 95-106.

Björnsson, H., 2002, Subglacial lakes and jökulhlaups in Iceland: Global and Planetary Change, 35, 255-271.

Carrivick, J.L., in press, Hydrodynamics and geomorphic work of jökulhlaups (glacial outburst floods) from Kverkfjöll volcano, Iceland: Hydrological Processes. Available online 31/07/06. DOI: 10.1002/hyp.6248

Carrivick, J.L., 2006, 2D modelling of high-magnitude outburst floods; an example from Kverkfjöll, Iceland: Journal of Hydrology, 321, 187-199.

Carrivick, J.L., 2005, Characteristics and impacts of jökulhlaups (glacial outburst floods) from Kverkfjöll, Iceland Keele University Ph.D. thesis. 420 pp.

Carrivick, J.L., and Twigg, D., 2004, Jökulhlaup-influenced topography and geomorphology at Kverkfjöll, Iceland: Journal of Maps, 2005, 17-27.

Carrivick, J.L., Russell, A.J., and Tweed, F.S., 2004a, Geomorphological evidence for jökulhlaups from Kverkfjöll volcano, Iceland: Geomorphology, 63, 81-102.

Carrivick, J.L., Russell, A.J., Tweed, F.S., and Twigg, D., 2004b, Palaeohydrology and sedimentology of jökulhlaups from Kverkfjöll, Iceland: Sedimentary Geology, $172,19-40$
Cassidy, N.J., Russell, A.J., Pringle, J.K., and Carrivick, J.L., 2004, GPR-derived architecture of large-scale Icelandic jökulhlaup deposits, NE Iceland 10th International Conference on Ground Penetrating Radar, 21-24th June, Delft, The Netherlands.

Cassidy, N.J., Russell, A.J., Marren, P.M., Fay, H., Knudsen, O., Rushmer, E.L., and van Dijk, T.A.G.P., 2003, GPR derived architecture of November 1996 jökulhlaup deposits, Skeiðarársandur, Iceland, in Ground Penetrating Radar in Sediments, Bristow, C.S., and Jol, H.M. (eds.), Geological Society of London Special Publications, 211, 153-166.

Cenderelli, D.A., and Wohl, E.E., 2003, Flow hydraulics and geomorphic effects of glacial-lake outburst floods in the Mount Everest region, Nepal: Earth Surface Processes and Landforms, 28, 385-407.

Chester, D.K., Degg, M., Duncan, A.M., and Guest, J.E., 2001, The increasing exposure of cities to the effects of volcanic eruptions: a global survey: Environmental Hazards, 2, 89-103.

Clague, J.J., and Evans, S.G., 2000, A review of catastrophic drainage of moraine-dammed lakes in British Columbia: Quaternary Science Reviews, 19, 1,763-1,783.

Costa, J.E., and Schuster, R.L., 1988, The formation and failure of natural dams: Geological Society of America Bulletin, 100, 1,054-1,068.

Cronin, S.J., Neall, V.E., Lecointre, J.A., and Palmer, A.S., 1997, Changes in Whangaehu river lahar characteristics during the 1995 eruption sequence, Ruapehu volcano, New Zealand: Journal of Volcanology and Geothermal Research, 76(1-2), 47-61.

Desloges, J.R., and Church, M., 1992, Geomorphic implications of glacier outburst flooding: Noeick River valley, British Columbia: Canadian Journal of Earth Sciences, 29, 551-564.

Gomez, B.S., Russell, A.J., Smith, L.C., and Knudsen, Ó., 2002, Erosion and deposition in the proglacial zone: the 1996 jökulhlaup on Skeiðarársandur, southeast Iceland, in The Extremes of the Extremes: Extraordinary Floods, Snorrason, A., Finnsdóttir, A.P., and Moss, M. (eds.), Proceedings of a Symposium at Reykjavík, July 2000. IAHS Publ. no. 271, IAHS Press, Wallingford, Oxfordshire, U.K. 217-221.

Haerberli, W., 1983, Frequency and characteristics of glacier floods in the Swiss Alps: Annals of Glaciology, 4, 85-90.

Haeberli, W., Alean, J-C., Muller, P., and Funk, M., 1989, Assessing the risks from glacier hazards in high mountain regions: some experiences in the Swiss Alps: Annals of Glaciology, 13, 77-101.

IPCC, 2001, Climate Change 2001, The Scientific Basis, in Contribution of Working Group I to the Third Assessment Report of the Intergovernmental Panel on Climate Change (IPCC), Houghton, J.T., Ding, Y., Griggs, D.J., Noguer, M., van der Linden, P.J., and Xiaosu, D. (eds.), Cambridge University Press, U.K.

Iverson, R.M., 1997, The physics of debris flows: Reviews of Geophysics, 35, 245-296.

Kochel, R.C., and Baker, V.R., 1988, Palaeoflood analysis using slackwater deposits. in Flood Geomorphology, 


\section{Carrivick et al.: GPR-Derived Sedimentary Architecture}

Baker, V.R., Kochel, R.C., and Patton, P.C. (eds.), John Wiley and Sons, New York. 357-376.

Lliboutry, L., Arno, B.M., Pautre, A., and Schneider, B., 1977, Glaciological problems set by the control of dangerous lakes in Cordillera Blanca, Peru. I: historical failures of moraine dams, their causes and prevention: Journal of Glaciology, 18, 239-254.

Maizels, J.K., 1993, Lithofacies variations within sandur deposits: the role of runoff regime, flow dynamics and sediment supply characteristics: Sedimentary Geology, 85, 299-325.

Maizels, J.K., 1997, Jökulhlaup deposits in proglacial areas: Quaternary Science Reviews, 16, 793-819.

Maizels, J.K., and Russell, A.J., 1992, Quaternary perspectives on jökulhlaup prediction: Quaternary Proceeedings, 2, 133-152.

Marren, P.M., 2005, Magnitude and frequency in proglacial rivers: a geomorphological and sedimentological perspective: Earth Science Reviews, 70, 203-251.

O'Connor, J.E., 1993. Hydrology, hydraulics and geomorphology of the Bonneville Flood. Geological Society of America Special Papers, 274, 83 pp.

Richardson, S.D., and Reynolds, J.M., 2000, An overview of glacial hazards in the Himalayas: Quaternary International, 65/66, 31-47.

Rushmer, E.L., in press, Technical Communication: Physicalscale modelling of jökulhlaups (glacial outburst floods) with contrasting hydrograph shapes. Earth Surface Processes and Landforms. Available online 22/11/06. DOI/10.1002/esp.1461

Rushmer, E.L., 2006, Sedimentological and geomorphological impacts of the jökulhlaup (glacial outburst flood) in January 2002 at Kverkfjöll, northern Iceland/: Geografiska Annaler, 88A(1), 1-11.

Rushmer, E.R., Russell, A.J., Tweed, F.S., Knudsen, Ó., and Marren, P.M., 2002, The role of hydrograph shape in controlling glacier outburst flood (jökulhlaup) sedimentation: in The Structure, Function and Management of Fluvial Sedimentary Systems, Dyer, F.J., Thomas, M.C., and Olley, J.M. (eds.), Proceedings of an International Symposium held in Alice Springs, Australia, September 2002, IAHS Publ. no. 276: 305-313.

Russell, A.J., M.J. Roberts., H. Fay., P.M. Marren., N.J. Cassidy., F.S. Tweed., and T. Harris., 2006, Icelandic jökulhlaup impacts: implications for ice-sheet hydrology, sediment transfer and geomorphology: Geomorphology, 75, 33-64.

Russell, A.J., 1996, Hydrology, hydraulics and geomorphology of the Bonneville flood by J.E. O'Conner: a review: Journal of Quaternary Science, 11, 431-432.

Russell, A.J., and Knudsen, Ó., 1999, Controls on the sedimentology of the November 1996 jökulhlaup deposits, Skeiðarársandur, Iceland, in Advances in Fluvial Sedimentology, Smith, N.D., Rogers, J., and Plint, A. (eds.), Blackwell Science, Oxford, 315-329.

Russell, A.J., and Marren, P.M., 1999, Proglacial fluvial sedimentary sequences in Greenland and Iceland: a case study from active proglacial environments subject to jökulhlaups, in The Description and Analysis of Quaternary Stratigraphic Field Sections, Jones, A.P., Hart, J.K., and Tucker, M.E. (eds.), QRA Technical Guide no. 7, QRA London: 171-208.

Simkin, T., Siebert, L., and Blong, R., 2001, Volcano fatalities-lessons from the historical record: Science, 291(5,502), $255 \mathrm{pp}$.

Scott, K.M., Macías, J.L., Naranjo, J.A., Rodriguez, S., and McGeehin, J.P., 2001, Catastrophic debris flows transformed from landslides in volcanic terrains: mobility, hazard assessment and mitigation strategies: U.S. Geological Survey Professional Paper, 1,630.

Tómasson, H., 2002, Catastrophic floods in Iceland: in The Extremes of the Extremes: Extraordinary Floods, Snorrason, A., Finnsdóttir, A.P., and Moss, M. (eds.), Proceedings of a Symposium at Reykjavík, July 2000. Publ. no. 271, IAHS Press, Wallingford, Oxfordshire, U.K., 121-126.

Tweed, F.S., and Russell, A.J., 1999, Controls on the formation and sudden drainage of glacier-impounded lakes: implications for jökulhlaup characteristics: Progress in Physical Geography, 23, 79-110.

Waythomas, C.F., and Wallace, K.L., 2002, Flank collapse at Mount Wrangell, Alaska, recorded by volcanic massflow deposits in the Copper River lowland: Canadian Journal of Earth Sciences, 39(8), 1,257-1,279.

Witham, C.S., 2005, Volcanic disasters and incidents: a new database: Journal of Volcanology and Geothermal Research, 148, 191-233. 